\title{
Changes in pituitary secretion during the early postnatal period and anovulatory syndrome induced by neonatal oestrogen or androgen in rats
}

\author{
L. Pinilla, E. Trimiño, P. Garnelo, C. Bellido, R. Aguilar, F. Gaytán \\ and E. Aguilar \\ Department of Physiology and Biology Section, School of Medicine, University of Córdoba, Spain
}

\begin{abstract}
The following experiments were performed: (i) concentrations of follicle-stimulating hormone (FSH), luteinizing hormone ( $\mathrm{LH})$ and prolactin in plasma were measured at 2, 5, 8, 10 and 15 days in female Wistar rats treated on the first day of life with $100 \mu \mathrm{g}$ oestradiol benzoate or vehicle; (ii) females injected on day I with $100 \mu \mathrm{g}$ of oestradiol benzoate or $1 \mathrm{mg}$ of testosterone propionate and from day 1 to day 10 or 15 with FSH and LH were killed on day 90; (iii) females injected from day 1 to day 10 or 15 with prolactin or vehicle were killed on day 90; (iv) females injected on day 1 with oestradiol benzoate and from day 1 to day 15 with a luteinizing-hormone-releasing hormone (LHRH) agonist were killed on day 90; $(\mathrm{v})$ groups of females injected on days 1, 4, 7, 10, 13 and 16 with an LHRH antagonist were killed on day 90 . Onset of puberty, vaginal cycles, organ weights and hormonal plasma concentrations were measured. Females treated on the first day of life with $100 \mu \mathrm{g}$ oestradiol showed inhibition of gonadotrophin secretion and stimulation of prolactin secretion during the neonatal period. Females injected on the first day of life with oestradiol benzoate or testosterone propionate showed, in adulthood, anovulation, ovarian atrophy, reduced FSH plasma concentrations, increased prolactin plasma concentrations and reduced pituitary prolactin content. These alterations were due neither to blocked gonadotrophin secretion nor to stimulated prolactin secretion observed immediately after steroid injection, since: (i) development of the anovulatory syndrome was not blocked by the administration of exogenous gonadotrophins or LHRH-agonist; and (ii) blockade of gonadotrophin secretion immediately after birth with an LHRH antagonist or neonatal injection of prolactin did not induce the anovulatory syndrome. It is concluded that anovulation induced by administration of neonatal steroid was mediated neither by the early inhibition of gonadotrophin secretion nor by the stimulation of prolactin secretion.
\end{abstract}

\section{Introduction}

The role of the neonatal pituitary in the organization of reproductive function is different in female and male rats. Neonatal administration of luteinizing-hormone-releasing hormone (LHRH) antisera or antagonists induced permanent changes in males (Bercu et al., 1977; Kolho et al., 1988; Kolho and Huhtaniemi, 1989), but not in females (van den Dungen et al., 1989).

Neonatal injection of androgens or oestrogens induced permanent anovulation in female rats (Barraclough, 1961; Gorski, 1963). The reduced effectiveness of steroids when injected simultaneously with neuroactive drugs (Kikuyama, 1961; Raum and Swerdloff, 1981; González-Mariscal et al., 1982; Vidal et al., 1986) and the morphological changes observed in the hypothalamus (Gorski, 1983) suggest that steroids act at the level of the brain, and, during the last decades, it has been assumed that neonatal steroids affect brain structures irreversibly and induce anovulation. It is therefore possible that different mechanisms are involved in the effects of

Received 15 November 1991 steroids (Gorski, 1990), and a pituitary or ovarian site of action cannot be excluded (Fink, 1990). This possibility is supported by the following experimental findings: (i) the reduced concentrations of gonadotrophins in plasma and the increase in concentrations of prolactin observed in males shortly after neonatal oestrogenization (Aguilar et al., 1987; Pinilla et al., 1989), and the blockade of the effects of neonatal oestrogenization by the simultaneous administration of gonadotrophins (Bellido et al., 1990); (ii) the existence of a delayed anovulatory syndrome induced by low doses of steroids, which appears several weeks after puberty (Swanson and van der Werff Ten Bosch, 1964a, b; Ericsson and Baker, 1966; Arai and Gorski, 1968) and is mediated by ovarian alterations (Napoli and Gerall, 1970); (iii) recent data showing that oestrogens in adulthood induce reversible changes in the neurones of the arcuate nucleus (Naftolin et al., 1990); and (iv) the inhibition of masculinization of neonatal males after suppression of the secretion of gonadotrophins by dihydrotestosterone (van der Schoot et al., 1976).

Thus, the following experiments were designed to establish (i) the pituitary secretion immediately after neonatal oestrogenization; (ii) the capacity of gonadotrophins and LHRH to block 
the effects of neonatal oestrogenization and androgenization; and (iii) the effects of the blockade of neonatal gonadotrophin secretion after administration of an LHRH antagonist and of neonatal prolactin administration on the reproductive function in adulthood.

Our results indicate that the anovulatory syndrome induced by neonatal steroid treatment is not mediated by changes in gonadotrophin secretion during the early postnatal period. Neonatal prolactin concentrations are unrelated to reproductive function in adult female rats.

\section{Materials and Methods}

\section{Animals and drugs}

Female Wistar rats were raised in our laboratory under controlled light ( $12 \mathrm{~h}$ light: $12 \mathrm{~h}$ darkness; lights on at 07:00 h) and temperature $\left(20 \pm 2^{\circ} \mathrm{C}\right)$. The day when the litters were born was considered as day 1 . At that moment, the litter size was adjusted to eight animals, which were weaned on day 21 and housed in groups (four to five per cage). Oestradiol benzoate, testosterone propionate and the LHRH-agonist Dala $^{6-}$ D-Gly ${ }^{10-}$ LHRH-ethylamide were obtained from Sigma (St Louis, MO). The LHRH antagonist Org.30276 (Ac-DpClPhe--DpClPhe-D-Trp-Ser-Tyr-D-Arg-Leu-Arg-Pro-D-Ala$\mathrm{NH}_{2} \mathrm{CH}_{3} \mathrm{COOH}$ ) was generously supplied by Organon (Oss, Netherlands). FSH (NIADDK oFSH-16), LH (USDA bLH-B-5) and prolactin (NIADDK oPrl-18) were supplied by the NIADDK (Bethesda, MD).

\section{Experiment 1}

On day 1 , females were injected subcutaneously $(0.1 \mathrm{ml})$ with either $100 \mu \mathrm{g}$ oestradiol benzoate or olive oil. Control and oestrogenized females were decapitated at the ages of 2, 5, 8, 10 and 15 days. Trunk blood was collected and the serum was separated by centrifugation and stored at $-20^{\circ} \mathrm{C}$ until assayed. The samples from the first days of the study from several animals were pooled; pituitaries were homogenized in $1 \mathrm{ml}$ physiological saline containing urea $\left(2.5 \mathrm{~mol} \mathrm{l}^{-1}\right)$ and subjected to ultrasonic treatment (Haggi and Aoki, 1981). Samples were centrifuged at $2800 \mathrm{~g}$ for $10 \mathrm{~min}$ and the supernatants frozen at $-20^{\circ} \mathrm{C}$ until analysed for hormone content.

\section{Experiment 2}

On day 1 , female pups were injected s.c. $(0.1 \mathrm{ml})$ with $100 \mu \mathrm{g}$ oestradiol benzoate (oestrogenized females), I $\mathrm{mg}$ of testosterone propionate (androgenized females) or olive oil (control females). The animals were submitted to a combined treatment with FSH $(80 \mu \mathrm{g}$ per $100 \mathrm{~g}$ body weight) and $\mathrm{LH}(40 \mu \mathrm{g}$ per $100 \mathrm{~g}$ body weight), or vehicle $(0.5 \%$ bovine serum albumin (BSA) in $0.9 \% \mathrm{NaCl}$ ), subcutaneously, once a day from day 1 to day 10 . Other groups of oestrogenized animals received higher doses of FSH $(100 \mu \mathrm{g}$ per $100 \mathrm{~g}$ body weight) and $\mathrm{LH}(50 \mu \mathrm{g}$ per $100 \mathrm{~g}$ body weight), twice a day, from day $\mathrm{I}$ to day 15 . The rats were inspected at least once a day for vaginal opening. Thereafter, the vaginal cytology was monitored daily. Animals were decapitated in the first dioestrus after day 90. The weights of animals, ovaries, uteri, adrenals and pituitary glands were recorded.

\section{Experiment 3}

Animals were injected subcutaneously with ovine prolactin (200 $\mu \mathrm{g}$ per $100 \mathrm{~g}$ body weight from day 1 to day 10 or with $400 \mu \mathrm{g}$ per $100 \mathrm{~g}$ body weight from day $\mathrm{I}$ to day 15$)$ given as two injections at $08: 00$ and 22:00 h. Control groups received vehicle $\left(0.15 \mathrm{~mol} \mathrm{NaCl}^{-1}, 0.03 \mathrm{~mol} \mathrm{NaCO}_{3} \mathrm{H} \mathrm{l}^{-1}, 0.1 \% \mathrm{BSA}\right.$, $\mathrm{pH}$ 9) twice a day. Additionally, female rats were injected from day 21 to vaginal opening with vehicle $(n=4)$ or the highest dose of prolactin $(n=3)$. Experimental procedure was similar to that in Expt 2.

\section{Experiment 4}

Female rats injected with oestradiol on day 1 were injected from day 1 to day 15 with the LHRH-agonist (in doses of 0.02 , 0.2 and $2 \mu \mathrm{g} \mathrm{kg}^{-1} \mathrm{day}^{-1}$, divided into two injections given at 08:00 and 22:00 h). Blood samples were obtained by jugular venepuncture after ether anaesthesia on day 15, $2 \mathrm{~h}$ after the last vehicle or LHRH-agonist injection. Thereafter, the animals were studied as in Expt 2.

\section{Experiment 5}

Female rats received an s.c. injection of either $500 \mu \mathrm{g}$ per $100 \mathrm{~g}$ body weight of LHRH-antagonist or of saline at days 1 , $4,7,10,13$ and 16 of age. Groups of rats were killed by decapitation on day 10 or maintained until day 90 . At the time rats were killed, trunk blood was collected and pituitaries, ovaries and uteri were dissected, weighed and frozen. In rats maintained until adulthood, the onset of puberty and vaginal cycles were recorded.

\section{Assays}

Concentrations of LH, FSH and prolactin in serum and pituitary were determined by a double-radioimmunoassay method using kits supplied by the NIADDK (Bethesda, MD). Rat LH-I-6, rFSH-I-6 and rPrl-I-5 were labelled with ${ }^{125}$ I by the chloramine T method (Greenwood et al., 1983). The LH, FSH and prolactin concentrations are expressed using rLH-RP-2, rFSH-RP-2 and rPrl-RP-3 as standards. Concentrations of oestradiol in plasma were measured using a kit from Diagnostics Products Corporation (Los Angeles, CA). All samples were measured in duplicate in the same assay, the intra-assay variations being $6,7,9$ and $8 \%$, respectively. The sensitivities were $7.5,20,10$ and $1 \mathrm{pg}$ for $\mathrm{LH}, \mathrm{FSH}$, prolactin and oestradiol, respectively.

\section{Statistical analysis}

Data are expressed as means \pm SEM. Statistical analyses were carried out by the Student's $t$ test or by two-way analysis of 

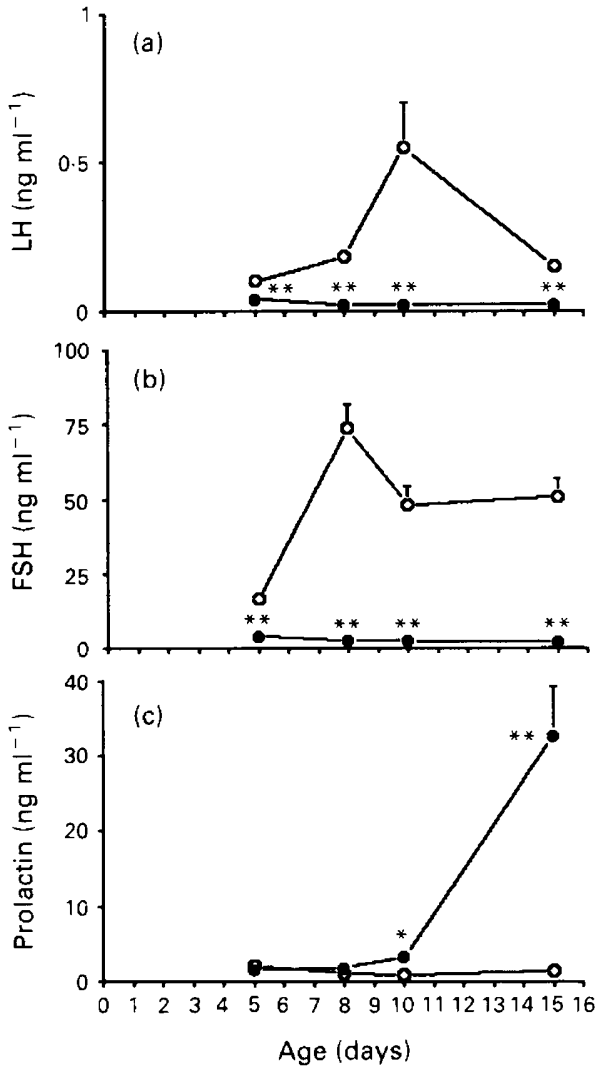

Fig. 1. Concentration of (a) luteinizing hormone (LH), (b) folliclestimulating hormone (FSH) and (c) prolactin in plasma in female rats injected on day 1 with vehicle $(O)$ or $100 \mu \mathrm{g}$ of oestradiol benzoate (O). Values are means \pm SEM (note the linear scale and that SEM is not given when bar is smaller than the symbols used in the figure). Each group consisted of $10-12$ animals; ${ }^{*}$ and ${ }^{* *} P \leqslant 0.05$ and 0.01 , respectively, compared with control groups (ANOVA followed by Tukey's test).

variance (ANOVA) and Tukey's multiple-comparison method for comparison among means.

\section{Results}

\section{Hormonal concentrations in neonatal female rats}

Control animals showed great variability in the plasma concentration of LH, which increased after day 5 and decreased on day 15. Oestrogenized females showed lower concentrations at 5, 8, 10 and 15 days. Plasma concentrations of FSH increased after day 5 in control animals and were significantly lower in oestrogenized females at 5, 8, 10 and 15 days. Prolactin plasma concentrations were higher in oestrogenized females at 10 and 15 days (Fig. 1). Pituitary FSH and LH content was significantly reduced and pituitary prolactin content increased in oestrogenized females (Fig. 2).

\section{Effects of neonatal administration of gonadotrophins, steroids or both}

Neonatal administration of oestrogen induced precocious vaginal opening, which occurred at lower body weights than in
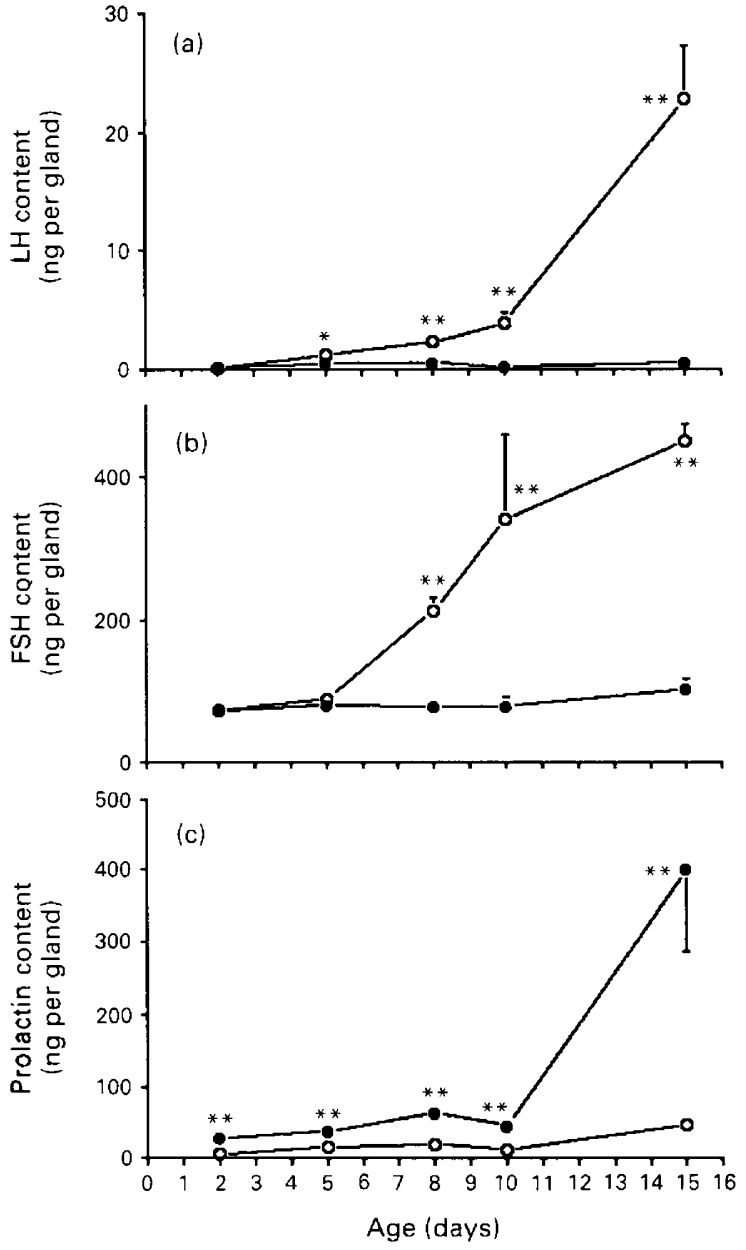

Fig. 2. (a) Pituitary luteinizing hormone (LH), (b) follicle-stimulating hormone ( $\mathrm{FSH}$ ) and (c) prolactin content in female rats injected on day 1 with vehicle $(O)$ or $100 \mu \mathrm{g}$ of oestradiol benzoate $(O)$. Values are means \pm SEM (note the linear scale and that SEM is not given when bar is smaller than the symbols used in the figure). Each group consisted of $10-12$ animals; $^{*}$ and ${ }^{* *} P \leqslant 0.05$ and 0.01 , respectively, compared with control groups (ANOVA followed by Tukey's test).

controls. In contrast, females injected with testosterone had no vaginal opening. Neonatal injection of gonadotrophins did not modify the onset of puberty in controls or in oestrogenized and androgenized females (Table 1).

Oestrogenized females showed anovulatory cycles characterized by alternately long periods of oestrus and dioestrus. The regular vaginal cycles in control females and the anovulatory cycles in oestrogenized females were unaffected by neonatal treatment with gonadotrophins (Table 1 ).

Ovaries from androgenized and oestrogenized females treated or not with gonadotrophins were atrophied on day 90 (Fig. 3), and the absence of fresh corpora lutea was revealed by histological examination.

Anovulatory female rats showed reduced FSH and increased prolactin plasma concentrations (Fig. 4). Pituitary concentrations of prolactin were reduced (Fig. 4), whereas those of FSH and $\mathrm{LH}$ were unaltered (data not shown). 
Table 1. Effects of neonatal injections of oestradiol benzoate, testosterone propionate, gonadotrophins, prolactin and luteinizinghormone-releasing-hormone (LHRH) agonist and antagonist on the age and body weight at vaginal opening and first oestrus and on the incidence of anovulation in rats

\begin{tabular}{|c|c|c|c|c|c|c|}
\hline \multirow[b]{2}{*}{ Treatment } & \multirow{2}{*}{$\begin{array}{c}\text { Number } \\
\text { of rats }\end{array}$} & \multicolumn{2}{|c|}{ Vaginal opening } & \multicolumn{2}{|c|}{ First oestrus } & \multirow{2}{*}{$\begin{array}{l}\text { Incidence of } \\
\text { anovulation } \\
(\%)\end{array}$} \\
\hline & & Age (days) & Weight $(g)$ & Age (days) & Weight (g) & \\
\hline Oil + vehicle & 8 & $39.13 \pm 1.24$ & $114 \pm 4.7$ & $41.3 \pm 1.1$ & $122 \pm 4$ & 0 \\
\hline Oestradiol benzoate + vehicle & 12 & $16.75 \pm 0.42^{* *}$ & $29 \pm 0.8^{* *}$ & & & 100 \\
\hline Testosterone propionate + vehicle & 6 & $\overline{N D}$ & $\overline{N D}$ & & & 100 \\
\hline Oil + gonadotrophins $^{\mathrm{a}}$ & 8 & $40.75 \pm 1.23$ & $115 \pm 3.5$ & $41.4 \pm 1.2$ & $123 \pm 5$ & 0 \\
\hline Oestradiol benzoate + gonadotrophins $s^{a}$ & 12 & $16.00 \pm 0.70$ & $25 \pm 1.0^{* *}$ & & & 100 \\
\hline Testosterone propionate + gonadotrophins $\mathrm{s}^{\mathrm{a}}$ & 7 & ND & ND & & & 100 \\
\hline Oestradiol benzoate + vehicle & 9 & $18.10 \pm 0.30$ & $26 \pm 1.1$ & & & 100 \\
\hline Oestradiol benzoate + gonadotrophins $^{\mathrm{b}}$ & 10 & $19.00 \pm 0.27$ & $33 \pm 3.2$ & & & 100 \\
\hline Oil + vehicle & 6 & $39.80 \pm 0.90$ & $116 \pm 3.4$ & $41.4 \pm 1.2$ & $128 \pm 5$ & 0 \\
\hline Oestradiol benzoate + vehicle & 10 & $17.10 \pm 0.30$ & $32 \pm 0.9$ & & & 100 \\
\hline Oestradiol benzoate + LHRH-agonist $^{c}$ & 10 & $16.45 \pm 0.80$ & $34 \pm 0.7$ & & & 100 \\
\hline Oestradiol benzoate + LHRH-agonist ${ }^{d}$ & 10 & $17.25 \pm 0.90$ & $36 \pm 0.6$ & & & 100 \\
\hline Oestradiol benzoate + LHRH-agonist ${ }^{e}$ & 9 & $18.00 \pm 1.10$ & $38 \pm 0.5$ & & & 100 \\
\hline Vehicle & 13 & $39.90 \pm 1.10$ & $109 \pm 1.7$ & $42.9 \pm 1.8$ & $121 \pm 7.2$ & 0 \\
\hline Prolactin $^{f}$ & 18 & $39.50 \pm 0.60$ & $114 \pm 2.5$ & $42.6 \pm 1.0$ & $124 \pm 3.3$ & 0 \\
\hline Vehicle & 9 & $35.50 \pm 0.80$ & $133 \pm 4.2$ & $41.1 \pm 2.1$ & $127 \pm 6.4$ & 0 \\
\hline Prolactin $^{8}$ & 7 & $35.10 \pm 0.90$ & $129 \pm 9.7$ & $42.4 \pm 1.8$ & $129 \pm 5.6$ & 0 \\
\hline Vehicle & 18 & $38.83 \pm 1.14$ & $123 \pm 3.6$ & $40.7 \pm 1.5$ & $139 \pm 5.1$ & 0 \\
\hline LHRH-antagonist $^{\mathrm{h}}$ & 18 & $33.44 \pm 2.16^{* *}$ & $95 \pm 7.2^{* *}$ & $37.5 \pm 0.6^{* *}$ & $118 \pm 4.4^{* *}$ & 0 \\
\hline
\end{tabular}

Values are means $\pm \mathrm{SEM} .{ }^{* *} \mathrm{P} \leqslant 0.01$ versus respective oil control groups (ANOVA followed by Tukey's test).

${ }^{2} 80 \mu \mathrm{g}$ per $100 \mathrm{~g}$ body weight of follicle-stimulating hormone and $40 \mu \mathrm{g}$ per $100 \mathrm{~g}$ body weight of luteinizing hormone were injected daily from day 1 to day 10 .

${ }^{b} 100 \mu \mathrm{g}$ per $100 \mathrm{~g}$ body weight follicle-stimulating hormone and $50 \mu \mathrm{g}$ per $100 \mathrm{~g}$ body weight of luteinizing hormone were injected each $12 \mathrm{~h}$ from day 1 to day 15 .

$0.02 \mu \mathrm{g} \mathrm{kg}^{-1}$ day $^{-1}$ of LHRH-agonist were injected daily from day $\mathrm{I}$ to day 10 .

${ }^{\mathrm{d}} 0.2 \mu \mathrm{g} \mathrm{kg}^{-1}$ day $^{-1}$ of LHRH-agonist were injected daily from day 1 to day 10 .

${ }^{e} 2 \mu \mathrm{g} \mathrm{kg}{ }^{-1}$ day $^{-1}$ of LHRH-agonist were injected daily from day 1 to day 10 .

$200 \mu \mathrm{g}$ per $100 \mathrm{~g}$ body weight of prolactin were injected daily from day 1 to day 10 .

$8400 \mu \mathrm{g} \mathrm{kg}$ per $100 \mathrm{~g}$ body weight of prolactin were injected daily from day 1 to day 15 .

${ }^{h} 500 \mu \mathrm{g}$ per $100 \mathrm{~g}$ body weight of LHRH-antagonist were injected each $72 \mathrm{~h}$ from day 1 to day 16 .

ND: vaginal opening was not observed.

\section{Effect of neonatal administration of prolactin}

The age and body weight at which vaginal opening and first oestrus occurred were unaffected by neonatal administration of prolactin (Table 1) and advanced by 3.6 days in females injected from day 21 (data not shown). Females treated with prolactin showed regular vaginal cycles. Pituitary concentrations of $\mathrm{LH}$ and prolactin and concentrations of FSH in plasma in adulthood were greater in the females treated with low doses of prolactin during the neonatal period (Table 2). Similar findings were observed with the higher doses of prolactin (data not shown).

\section{Effects of neonatal administration of $L H R H$-agonist to oestrogenized females}

Reduced FSH and LH plasma concentrations and increased prolactin concentrations in oestrogenized females were also observed on day 15 at the end of treatments with different doses of LHRH-agonist (Fig. 5). Precocious vaginal opening and constant vaginal oestrus were observed in oestrogenized animals injected with different doses of LHRH-agonist (Table 1). Ovarian and uterine atrophy were observed on day 90 (Fig. 3). Absence of corpora lutea was confirmed by histological examination.

\section{Effects of neonatal administration of LHRH-antagonist}

Females injected with LHRH-antagonist showed, on day 10 , reduced $\mathrm{FSH}, \mathrm{LH}$ and oestradiol plasma concentrations, pituitary LH and FSH content and weight of uteri (Table 3). Vaginal opening and first oestrus were advanced (Table 1 ) and regular cycles were observed. Normal ovarian and uterine weights and FSH and LH plasma concentrations were observed on days 90 and 150 (data not shown).

\section{Discussion}

Dependence of ovarian function on pituitary secretion during the neonatal period begins in the first week of life. Specific 

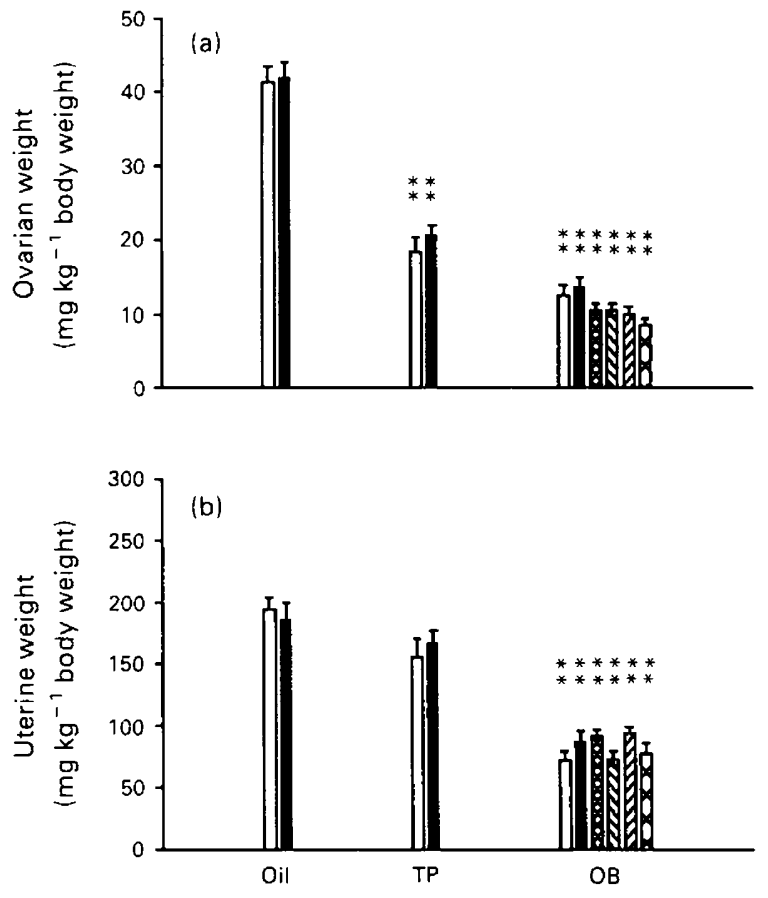

Fig. 3. (a) Ovarian and (b) uterine weights in adult female rats injected on day I with $0.1 \mathrm{ml}$ of oil, $100 \mu \mathrm{g}$ of oestradiol benzoate $(\mathrm{OB})$ or I mg of testosterone propionate (TP) and with vehicle ( $\square$ ), folliclestimulating hormone and luteinizing hormone from day 1 to day 10 (ם), or from day 1 to day 15 (田) or luteinizing-hormone-releasinghormone agonist $\left(\mathbb{Q}: 0.02 \mu \mathrm{g} \mathrm{kg}^{-1}\right.$ day $^{-1} ; \bigotimes: 0.2 \mu \mathrm{g} \mathrm{kg}^{-1}$ day $^{-1} ; \bigotimes$ : $2 \mu \mathrm{g} \mathrm{kg}^{-1}$ day $\left.^{-1}\right)$. Values are means \pm SEM. Each group consisted of $10-12$ animals; ${ }^{* *} P \leqslant 0.01$ compared with the corresponding oilinjected groups (ANOva followed by Tukey's test).

binding of LH and FSH has been detected on days 4 and 5 (Peluso et al, 1976; Smith-White and Ojeda, 1981b) and FSH increases ovarian cAMP production (Sokka and Huhtaniemi, 1990) and testosterone aromatization (Funkenstein et al., 1980) in 4-day-old rats. Prolactin receptors appear in the ovary at about I week of life (Huhtaniemi and Catt, 1981).

Assuming that neonatal gonadotrophin secretion is essential for development of ovarian FSH receptors (Smith and Ojeda, 1986) and that neonatal oestrogenization reduces gonadotrophin secretion and increases prolactin secretion at least until day 15 of life, when ovarian receptors for gonadotrophins and prolactin are present, the possibility that the anovulatory syndrome induced by neonatal oestrogenization or androgenization is mediated, at least in part, by changes initially induced in pituitary secretion was investigated. Doses of gonadotrophins used were higher than those needed to prevent testicular atrophy induced in male rats after neonatal injection of oestradiol benzoate (Bellido et al., 1990) or LHRH-antagonist (L. Pinilla, P. Garnelo and E. Aguilar, unpublished observations). Our results suggest that the anovulatory syndrome induced in female rats by neonatal oestrogen or androgen administration was mediated neither by the decrease in pituitary secretion of gonadotrophins, nor by the increase in prolactin secretion. The following findings supported this assumption: (i) development of the anovulatory syndrome was not blocked by the administration of either exogenous gonadotrophins or LHRH-agonist;
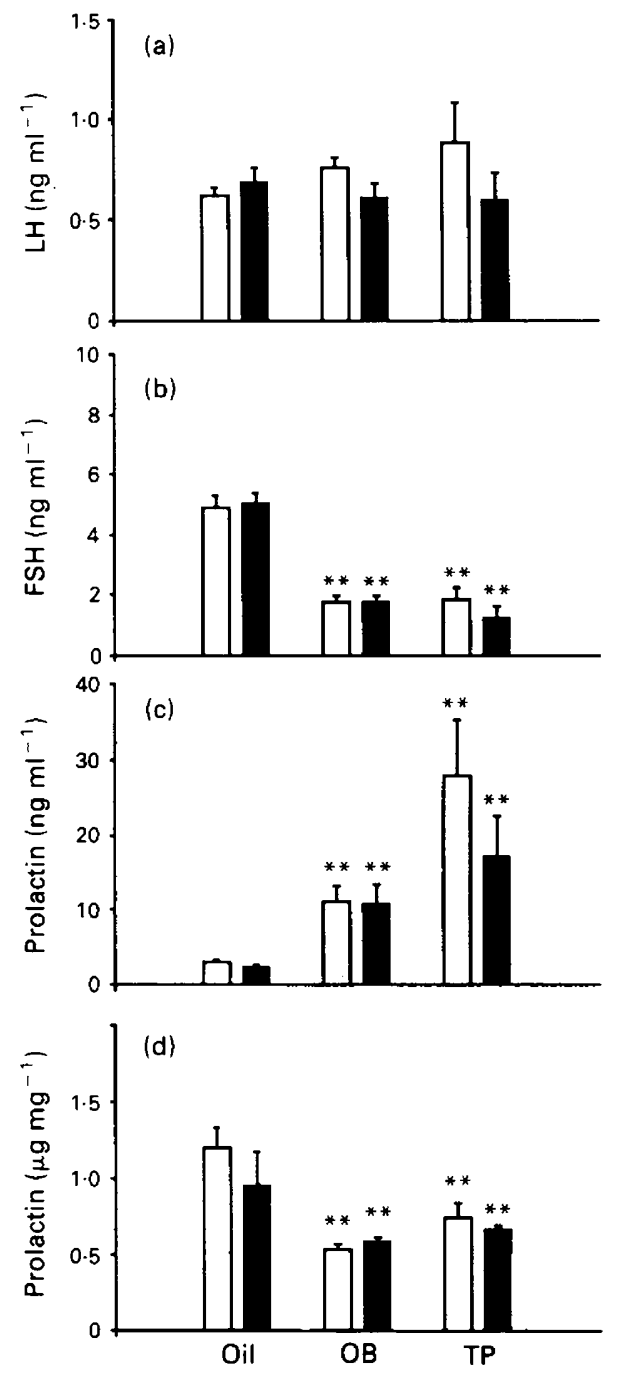

Fig. 4. Concentrations of (a) luteinizing hormone (LH), (b) folliclestimulating hormone (FSH) and (c) prolactin in plasma and (d) prolactin in pituitary in adult female rats injected on day 1 with $0.1 \mathrm{ml}$ of oil (Oil), $100 \mu \mathrm{g}$ of oestradiol benzoate (OB) or $1 \mathrm{mg}$ of testosterone propionate (TP) and from day 1 to day 10 with vehicle $(\square)$ or FSH and LH (ם). Values are means \pm SEM. Each group consisted of 10-12 animals; ** $P \leqslant 0.01$ compared with respective oil-injected groups (ANOVA followed by Tukey's test).

(ii) blockade of gonadotrophin secretion immediately after birth with an LHRH-antagonist or neonatal injection of prolactin did not induce the anovulatory syndrome. Doses of steroids injected were large and traditionally used to ensure complete sterilization. The possibility that gonadotrophins prevent the 'delayed anovulatory syndrome' induced by administration of lower doses of steroids (Swanson and van der Werff Ten Bosch, 1964a, b; Ericsson and Baker, 1966) needs further study.

Our results contrast with those showing that the sterilizing effect of testosterone injected into neonatal rats was mediated by a decrease in gonadotrophin secretion and that the changes induced by puberty, ovarian cycle and sexual behaviour could be blocked by neonatal gonadotrophin administration (Sheridan et al., 1973) despite the administration of higher doses of 
Table 2. Effects of daily s.c. injections of prolactin $\left(2 \mathrm{mg} \mathrm{kg}^{-1}\right.$ from day 1 to day 10 ) on concentrations of follicle-stimulating hormone (FSH), luteinizing hormone ( $\mathrm{LH})$ and prolactin in pituitary and plasma in adult female rats

\begin{tabular}{|c|c|c|}
\hline & \multicolumn{2}{|c|}{ Treatment } \\
\hline & $\begin{array}{l}\text { Vehicle } \\
(n=12)\end{array}$ & $\begin{array}{l}\text { Prolactin } \\
(n=18)\end{array}$ \\
\hline \multicolumn{3}{|c|}{$\begin{array}{l}\text { Concentration in } \\
\text { pituitary (ng } \mathrm{mg}^{-1} \text { ) }\end{array}$} \\
\hline FSH & $42.4 \pm 1.9$ & $44.8 \pm 2.7$ \\
\hline LH & $106 \pm 12$ & $180 \pm 17^{* *}$ \\
\hline Prolactin & \pm 50 & $\pm 40^{* *}$ \\
\hline \multicolumn{3}{|c|}{ 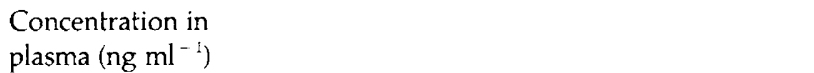 } \\
\hline FSH & $4.17 \pm 0.2$ & $5.68 \pm 0.23^{* *}$ \\
\hline LH & $0.57 \pm 0.05$ & $0.59 \pm 0.04$ \\
\hline Prolactin & $2.30 \pm 0.34$ & $2.25 \pm 0.40$ \\
\hline
\end{tabular}

Values are means $\pm \mathrm{SEM} .{ }^{* *}$ Significantly different from control, $P \leqslant 0.01$ (Student's + test).

FSH: follicle stimulating hormone; LH: luteinizing hormone.

gonadotrophins during a longer period. However, our results are consistent with the normal reproductive function described in adult females, in which neonatal secretion of gonadotrophins is blocked with LHRH-agonist (Aguilar et al., 1990) or antagonist (van den Dungen et al., 1989). Suppression of high concentrations of gonadotrophins in the first weeks of life retards follicle development prepubertally, but this is restored at the start of cyclical activity (Meijs-Roelofs et al., 1990).

It was demonstrated by Meijs-Roelofs et al. (1987) that LHRH-antagonist given to prepubertal females delayed onset of puberty only if the antagonist was given immediately before the preovulatory LH surge. The precocious puberty observed in our females treated with LHRH-antagonist from day 1 to day 15 seems paradoxical, but agrees with previous data (van den Dungen et al., 1989) and may be related to ovarian action, since LHRH-binding sites are present at 10 days of age (Dalkin et al., 1981), LHRH inhibits granulosa cell differentiation (Hsueh et al., 1984) and the ovarian steroidogenic responsiveness to gonadotrophins increases when the inhibitory local action of LHRH decreased (Smith-White and Ojeda, 1981a).

The only mechanism that is probably involved in the anovulatory syndrome induced by neonatal steroid injection is a permanent alteration in the central nervous system. The volume of the hypothalamic sexually dimorphic nucleus in adulthood is permanently modified in female rats injected shortly after birth with testosterone propionate or the antioestrogen tamoxifen (Gorski, 1983), and sexual differences in postsynaptic membranes of the hypothalamic arcuate nucleus are abolished by oestrogens (Naftolin et al., 1990).

Clear sex differences in reproductive alterations after neonatal steroid injection can be observed. Male rats treated with oestradiol on the first day of life show low gonadotrophin concentrations, either in serum or the hypophysis, in the early postnatal period (Aguilar et al., 1987). The administration of FSH and LH from
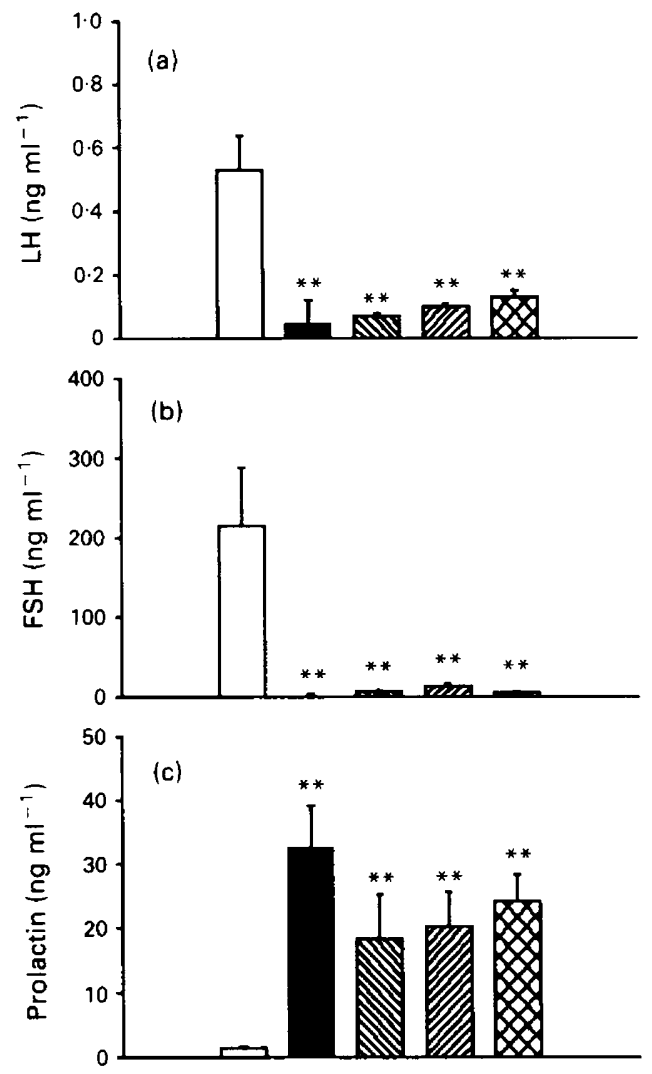

Fig. 5. (a) Luteinizing hormone (LH), (b) follicle-stimulating hormone (FSH) and (c) prolactin concentrations in plasma of 16-day-old female rats injected on day 1 with olive oil $(\square), 100 \mu \mathrm{g}$ of oestradiol benzoate $(\square)$ or oestradiol benzoate plus LH-releasing-hormone agonist $(\mathbb{Q}$ :

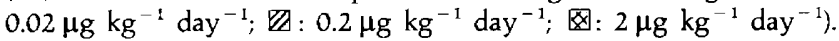
Values are means \pm SEM. Each group consisted of 10-12 animals; ** $P \leqslant 0.01$ compared with oil-injected group (ANOVA followed by Tukey's test).

Table 3. Hormone concentrations and organ weights on day 10 in female rats injected with LHRH-antagonist

\begin{tabular}{|c|c|c|c|}
\hline & \multicolumn{3}{|c|}{ Treatment } \\
\hline & \multicolumn{2}{|c|}{$\begin{array}{l}\text { Vehicle } \\
(n=8)\end{array}$} & $\begin{array}{l}\text { LHRH-antagonist } \\
\qquad(n=10)\end{array}$ \\
\hline Pituitary FSH (ng) & $629 \pm$ & 90 & $43 \pm 7.6^{* *}$ \\
\hline Pituitary LH (ng) & $248 \pm$ & 22 & $93 \pm 9.2^{* *}$ \\
\hline Plasma FSH $\left(\mathrm{ng} \mathrm{ml}^{-1}\right)$ & $58.6 \pm$ & 7.4 & $4.5 \pm 0.8^{* *}$ \\
\hline Plasma LH (ng ml $\left.\mathrm{ml}^{-1}\right)$ & $1.73 \pm$ & 0.4 & $0.17 \pm 0.02^{* *}$ \\
\hline 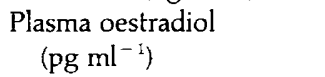 & $232 \pm$ & 119 & $1.6 \pm 0.9^{* *}$ \\
\hline $\begin{array}{l}\text { Ovarian weight } \\
\text { (mg kg }{ }^{-1} \text { body weight) }\end{array}$ & $9.55 \pm$ & 1.7 & $9.77 \pm 1.4$ \\
\hline $\begin{array}{l}\text { Uterine weight } \\
\text { (mg kg }{ }^{-1} \text { body weight) }\end{array}$ & $32.11 \pm$ & 1.2 & $25.47 \pm 1.7^{* *}$ \\
\hline
\end{tabular}

Values are means \pm SEM. ${ }^{* *} P \leqslant 0.01$ versus vehicle-injected group. FSH: follicle-stimulating hormone; LH: luteinizing hormone. 
day $I$ to day 10 abolished the effects of oestrogen (Bellido et al., 1990). Female rats treated with oestradiol or testosterone also showed a decrease in gonadotrophin secretion during the early postnatal period, but, in contrast, simultaneous injection of gonadotrophin did not abolish the effects of steroids.

It has been reported that neonatal prolactin deficiency induced in female pups by treatment of lactating mothers with bromocriptine induced oestrous acyclicity, hyperprolactinaemia and reduced turnover rates of dopamine in the median eminence (Shyr et al., 1986; Shah et al., 1988; Crowley et al., 1990) and that the administration of a prolactin antiserum to neonatal males reduced the pituitary prolactin content in adulthood and the diurnal prolactin surges (Mills et al., 1982).

Implantation of additional pituitaries or exogenous administration of prolactin has been used to induce an excess of prolactin during the neonatal period. The first approach seems to be inconclusive, since neonatal female rats grafted on day 5 with one additional pituitary exhibited increased prolactin plasma concentrations only after day 17 (Tresguerres et al., 1983). In the present work, we demonstrated that prolactin injected during the neonatal period at doses higher than those previously reported as effective (Jones et al., 1983; Chase and Payne, 1985) did not significantly alter the reproductive function in accordance with similar results obtained in males (Bellido ef al., 1990). The biological activity of prolactin was confirmed by precocious vaginal opening induced after its injection from day 21, a finding reported by Clemens et al. in 1969). The increased LH and prolactin pituitary content and the FSH values in plasma observed in adult females injected shortly after birth with prolactin suggest that, in spite of the regular reproductive cycles of these rats, subtle changes in the regulation of pituitary secretion occur.

The results demonstrate that in females, unlike males, sterility induced after neonatal steroid treatment was not mediated by the initial decrease in gonadotrophin secretion and that an excess of neonatal prolactin did not affect ovarian activity in adulthood, in clear contrast to data obtained by others after induction of neonatal prolactin deficiency (Shyr et al., 1986; Shah et al., 1988; Crowley et al., 1990).

The National Pituitary Agency supplied the radioimmunoassay materials for $\mathrm{FSH}$, $\mathrm{LH}$ and prolactin determinations. We thank T. Recio for invaluable technical help and I. Molina for typing the manuscript. This work was supported by grant 90-79 from DGICYT.

\section{References}

Aguilar E, Bellido C, Aguilar R, Pinilla L, Tejero A and Fernández Galaz C (1987) Mechanisms in the production of prepubertal reproductive defects in neonatal estrogenized male rats Andrologia 19 22-31

Aguilar E, Rodriguez Padilla ML, Garnelo P, Trimiño E and Pinilla L (1990) Transient blockade of the pituitary-gonadal function in female rats neonatally injected with an LHRH agonist Journal of Steroid Biochemistry 36 (Supplement) 49S

Arai Y and Gorski RA (1968) Critical exposure time for androgenization of the developing hypothalamus in the fernale rat Endocrinology 82 1010-1014

Barraclough CA (1961) Production of anovulatory, sterile rat by single injections of testosterone propionate Endocrinology $6862-67$

Bellido C, Pinilla L, Aguilar R, Gaytan F and Aguilar E (1990) Possible role of changes in post-natal gonadotrophin concentrations on permanent impairment of the reproductive system in neonatally oestrogenized male rats Journal of Reproduction and Fertility 90 369-374
Bercu BB, Jackson IMD, Sawin CT, Safaii H and Reichlin S (1977) Permanent impairment of testicular development after transient immunological blockade of endogenous luteinizing hormone releasing hormone in the neonatal rat Endocrinology 101 1871-1879

Chase DJ and Payne AH (1985) Prolactin involvement in regulation of testicular $5 \alpha$-reductase activity in the immature rat Biology of Reproduction $33637-643$

Clemens JA, Minaguchi H, Storey R, Voogt JL and Meites J (1969) Induction of precocious puberty in female rats by prolactin Neuroendocrinology 4 150-156

Crowley WR, Shah GV, Watanobe H and Grosvenor CE (1990) Effects of neonatal exposure to estradiol on prolactin secretion and activity of the tubero-infundibular dopamine system in young adulthood: comparison with neonatal prolactin deficiency Joumal of Neuroendocrinology 2 19-24

Dalkin AC, Bourne GA, Pieper DR, Regiani S and Marshall JC (1981) Pituitary and gonadal gonadotropin-releasing hormone receptors during sexual maturation in the rat Endocrinology 108 1658-1664

Ericsson RJ and Baker VF (1966) Sexual receptivity and fertility of female rats that are in androgen induced persistent estrus Proceedings of the Society for Experimental Biology and Medicine 112 88-92

Fink G (1990) Developmental aspects of the control of gonadotropin secretion before and during puberty. In Control of the Onset of Puberty pp 321-343 Eds MM Grumbach, PC Sizonenko and ML Aubert. Williams \& Wilkins Baltimore

Funkenstein B, Nimrod A and Lindner HR (1980) The development of steroidogenic capability and responsiveness to gonadotropins in cultured neonatal rat ovaries Endocrinology $10698-106$

González-Mariscal G, Fernández-Guasti A and Beyer C (1982) Anesthetic pregnanes counteract androgen-induced defeminization Neuroendocrinology 34 357-362

Gorski RA (1963) Modification of ovulatory mechanisms by postnatal administration of estrogen to the rat American Journal of Physiology 205 842-844

Gorski RA (1983) Steroid-induced sexual characteristics in the brain. In Neuroendocrine Perspectives Vol. 2 pp I-35 Eds EE Müller and RM MacLeod. Elsevier Science Publishers, Amsterdam

Gorski RA (1990) Sexual differentiation of the brain: comparative aspects. In Control of the Onset of Puberty pp 231-250 Eds MM Grumbach, PC Sizonenko and ML Aubert. Williams \& Wilkins, Baltimore

Greenwood FC, Hunter WM and Glover JS (1983) The preparation of ${ }^{125} \mathrm{I}-$ labelled human growth hormone on high specific radioactivity Biochemical Journal 89 114-123

Haggi E and Aoki A (1981) Prolactin content in rat pituitary gland. RIA of prolactin after different extraction procedures Acta Endocrinologica 97 338-342

Hsueh AJW, Adashi EY, Joners PBC and Welsh TH (1984) Hormonal regulation of the differentiation of cultured ovarian granulosa cells Endocrine Reviews 5 $76-127$

Huhtaniemi IT and Catt KJ (1981) Induction and maintenance of gonadotropin and lactogen receptors in hypoprolactinemic rats Endocrinology 109 483-490

Jones R, Rising PR and Parker MG (1983) Effects of prolactin on testosteroneinduced growth and protein synthesis in rat accessory sex glands Journal of Endocrinology 96 407-416

Kikuyama S (1961) Inhibitory effects of reserpine on the induction of persistent estrus by sex steroids in the rat Annotationnes Zoologica Japonica 34 114-116

Kolho KL and Huhtaniemi I (1989) Suppression of pituitary-testis function in rats treated neonatally with a gonadotrophin-releasing hormone agonist and antagonist: acute and long-term effects Journal of Endocrinology 123 83-91

Kolho KL, Nikula H and Huhtaniemi I (1988) Sexual maturation of male rats treated postnatally with a gonadotrophin-releasing hormone antagonist Journal of Endocrinology 116 241-246

Meijs-Roelofs HMA, Kramer P, van Capellen WA and Schuiling GA (1987) Inhibition of first ovulation: administration of an LHRH antagonist to immature female rats Journal of Endocrinology 112 407-415

Meijs-Roelofs HMA, van Capellen WA, van Leeuwen ECM and Kramer P (1990) Short- and long-term effects of an LHRH antagonist given during the prepubertal period on follicle dynamics in the rat Journal of Endocrinology $\mathbf{1 2 4}$ $247-253$

Mills DE, Buckman MT and Peake GT (1982) Neonatal treatment with antiserum to prolactin lowers blood pressure in rats Science 217 162-164

Naftolin F, Garcia-Segura LM, Keefe D, Leranth C, Maclusky NJ and Brawer JR (1990) Estrogen effects on the synaptology and neural membranes of the rat hypothalamic arcuate nucleus Biology of Reproduction 42 21-28

Napoli AM \& Gerall AA (1970) Effect of estrogen and anti-estrogen on reproductive function in neonatally androgenized female rats Endocrinology 87 1330-1337 
Peluso JJ, Steger RW and Hafez ESE (1976) Development of gonadotrophinbinding sites in the immature rat ovary Journal of Reproduction and Fertility 47 55-58

Pinilla L, López F, González D, Fernández-Galaz C, Sánchez Criado J and Aguilar E (1989) Luteinizing-hormone-mediated precocious puberty induced in female rats by a prepubertal pituitary graft Neuroendocrinology $\mathbf{5 0}$ 495-499

Raum WJ and Swerdloff RS (1981) The role of hypothalamic adrenergic receptors in preventing testosterone-induced androgenization in the male rat brain Endocrinology 109 273-278

Shah GV, Shyr SW, Grosvenor CE and Crowley WR (1988) Hyperprolactinemia after neonatal prolactin (PRL) deficiency in rats: evidence for altered anterior pituitary regulation of PRL secretion Endocrinology 122 1883-1889

Sheridan PI, Zarrow MX and Denenberg VH (1973) The role of gonadotropins in the development of cyclicity in the rat Endocrinology 92 500-508

Shyr SW, Crowley WR and Grosvenor CE (1986) Effect of neonatal prolactin deficiency on prepubertal tuberoinfundibular and tuberohypophyseal dopaminergic neuronal activity Endocrinology 119 1217-1221

Smith-White S and Ojeda SR (1981a) Changes in ovarian LHRH receptor content during the onset of puberty in the female rat Endocrinology 108 347-349

Smith-White S and Ojeda SR (198Ib) Changes in ovarian luteinizing hormone and follicle-stimulating hormone receptor content and in gonadotropininduced ornithine decarboxylase activity during prepubertal and pubertal development of the female rat Endocrinology 109 152-161
Smith SS \& Ojeda SR (1986) Neonatal release of gonadotropins is essential for development of ovarian follicle-stimulating hormone receptors Biology of Reproduction 34 219-227

Sokka T and Huhtaniemi I (1990) Ontogeny of gonadotrophin receptors and gonadotrophin-stimulated cyclic AMP production in the neonatal ovary Journal of Endocrinology 127 297-303

Swanson HE and van der Werff Ten Bosch J] (1964a) The 'early androgen' syndrome: its development and the response to hemi-spaying Acta Endocrinologica 45 1-12

Swanson HE and van der Werff Ten Bosch JJ (1964b) The 'early androgen' syndrome, differences in response to prenatal and postnatal administration in female and male rats Acta Endocrinologica $4737-50$

Tresguerres JAF, Esquifino AI and Calderón AL (1983) Effects of estradiol benzoate and castration on LH in experimental hyperprolactinemia Journal of Steroid Biochemistry 19 447-453

van den Dungen HM, van Dieten JAMJ, Tilders FJH, van Rees GP and Shoemacker J (1989) Administration of a GnRH-antagonist to immature rats affects subsequent female and male pubertal development differently Acta Endocrinologica $120778-784$

van der Schoot P, van der Vaart PDM and Vreeburg JTM (1976) Masculinization in male rats is inhibited by neonatal injections of dihydrotestosterone Journal of Reproduction and Fertility 48 385-387

Vidal MJ, López F, González D and Aguilar E (1986) Effect of neonatal testosterone administration and beta adrenergic stimulation on adult prolactin levels Revista Española de Fisiologia 42 139-142 